\title{
CARCASS CHARACTERISTICS OF SHEEP FED WITH CASTOR BEAN HULLS IN REPLACEMENT OF TIFTON 85 HAY
}

\author{
Características de carcaça de ovinos alimentados com casca \\ de mamona em substituição ao feno de capim Tifton 85
}

\author{
Stela Antas Urbanoㅁ, Marcelo de Andrade Ferreira², Wilson Moreira Dutra Junior ${ }^{2}$, Rafael de Paula Xavier de \\ Andrade $^{2}$, Michelle Christina Bernardo de Siqueira ${ }^{2}$, Sabrina Carla Rodrigues Félix ${ }^{2}$
}

\begin{abstract}
Castor bean hulls $(\mathrm{CBH})$, co-products of castor oil extraction, are high in dry matter (DM) and fiber and are emerging as alternative roughage in sheep feed. This could reduce feed costs since other sources of roughage can be more expensive. The effects of replacing Tifton 85 hay with $\mathrm{CBH}$ at $0,33,66$ and $100 \%$ in the diet of sheep on the carcass characteristics, weights and yields of retail cuts and carcass measurements were studied. Twenty-eight non-castrated sheep averaging $7 \pm 1.4$ months of age with an initial weight of $19.5 \pm 4.3 \mathrm{~kg}$ were slaughtered after 70 days of confinement. There was a linear decline $(P \leq 0.05)$ in slaughter body weight, empty body weight, hot and cold carcass weight and longissimus muscle area (LMA) as the percentage of dietary CBH increased. A linear decrease $(P \leq 0.05)$ of the weights of all retail cuts and a quadratic effect (minimum yield of $9.84 \%$ with the replacement of $56.9 \%)$ of the neck yield were also detected as the percentage of $\mathrm{CBH}$ increased. No treatment effects $(P>0.05)$ on the yield of the other cuts were observed, but there was a linear decline $(P \leq 0.05)$ in the perimeters of the thorax, leg and rump and the carcass compactness index. Replacing Tifton 85 hay with $\mathrm{CBH}$ in sheep diets is not recommended because it decreases the slaughter body weight, cold and hot carcass weight, retail cut weights and morphometric measurements.
\end{abstract}

Index terms: Biodiesel, morphometry, sheep production, Ricinus comunis L.

\section{RESUMO}

A casca da mamona, coproduto da extração do óleo da mamona, por apresentar em sua composição elevados teores de matéria seca e fibra, surge como fonte alternativa de volumoso na alimentação de ovinos, podendo diminuir os custos com alimentação, uma vez que outras fontes são comercializadas a preços superiores. Avaliou-se o efeito da substituição do feno de capim Tifton 85 pela casca de mamona em 0,33, 66 e 100\% na dieta de ovinos sobre as características de carcaça, os pesos e rendimentos dos cortes comerciais e a morfometria da carcaça. Vinte e oito animais não castrados, com $7 \pm 1,4$ meses de idade e peso inicial médio de $19,5 \pm$ $4,3 \mathrm{~kg}$, foram abatidos após 70 dias de confinamento. Houve efeito linear decrescente $(P \leq 0.05)$ para o peso corporal ao abate, peso de corpo vazio, peso de carcaça quente, peso de carcaça fria e área de olho-de-lombo, de acordo com os níveis crescentes de substituição. $\mathrm{O}$ decréscimo linear $(P \leq 0,05)$ no peso de todos os cortes comerciais e o efeito quadrático do rendimento do pescoço (rendimento mínimo de $9,84 \%$ quando a substituição foi de 56,9\%) também foram verificados com o aumento percentual da casca de mamona. Não houve efeito $(P>0,05)$ sobre os rendimentos dos demais cortes, mas o perímetro do tórax, da perna e da garupa e o índice de compacidade da carcaça decresceram linearmente $(P \leq 0,05)$ com a substituição. A substituição do feno de capim Tifton 85 pela casca de mamona para ovinos diminui o peso corporal ao abate, os pesos de carcaça quente e fria, os pesos dos cortes comerciais e as medidas morfométricas.

Termos para indexação: Biodiesel, morfometria, ovinocultura, Ricinus comunis L.

(Received in june 27, 2012 and approved in december 12, 2012)

\section{INTRODUCTION}

Investments in research with sheep and the application of this research in the field have resulted in the development of the Brazilian sheep industry, particularly in the northeast, and the increased productivity and profitability of this activity are already considerable. However, although the species is highlighted by its high potential for meat production, the lack of rainfall in the semiarid regions of the northeast has caused problems in nutrition, making dietary supplementation necessary during the dry season.

One of the most important constraints in tropical livestock production systems is underfeeding due to limitations in both the quantity and quality of the feed (MENDIETA-ARAICO, et al., 2011), which becomes more severe in semiarid regions. However, byproducts appear to be alternative ingredients in ruminant feed during periods of food shortage (MOLINA ALCAIDE; YÁÑES RUIZ, 2008).

1Universidade Federal Rural de Pernambuco/UFRPE - Departamento de Zootecnia - Brasil - stela_antas@yahoo.com.br ¿Universidade Federal Rural de Pernambuco/UFRPE - Brasil 
The downward trend in the use of petroleum-based energy sources in Brazil has been encouraging the production of renewable energy sources, such as biodiesel (BRUNSCHWIG et al., 2012). The cultivation of castor fruit has established a chain of biofuel production in semi-arid regions (CESAR; BATALHA, 2010). Castor bean hulls, coproducts of the castor oil extraction, contain high concentrations of dry matter and fiber and are thus emerging as alternative roughage in ruminant diets (GOMES ET AL., 2009; SANTOS et al., 2011). Their use could reduce feed costs because other sources of roughage such as Tifton 85 hay, sell for higher prices. Tifton 85 hay, widely recognized as having high nutritional value (ATAÍDE JÚNIOR et al., 2000), can cost US\$ $0.68 \mathrm{~kg}^{-1}$ during periods of food shortage, impairing the viability of animal production.

Carcass yield is important in the evaluation of animal production because it is directly related to the commercial value of the animal, being usually one of the first indexes to be considered. It is expressed as the percentage ratio between the carcass weight and live animal weight (ZUNDT et al., 2006). The proper conformation of the carcass indicates a proportional development of the different anatomical regions, and the best conformations are achieved when the parts with the greatest commercial value are well pronounced (OLIVEIRA et al., 2002). These objective and subjective measures can be used to evaluate the characteristics of a carcass (REIS et al., 2001), and estimating the carcass characteristics is important to complement the evaluation of the animal's performance during its development (JORGE et al., 1999).

The objective of this study was to evaluate the effect of Tifton 85 hay replacement by $\mathrm{CBH}$ on carcass yield and commercial cuts and on the carcass morphometry of feedlot sheep.

\section{MATERIALS AND METHODS}

The experiment was carried out at the goat and sheep farm of the Animal Science Department of the Universidade Federal Rural de Pernambuco, located in Recife-PE, Brazil, in the micro-physiographic region of Litoral da Mata, belonging to the Metropolitan Region of Recife. A total of 28 sheep (without defined breed) coming

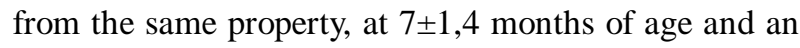
initial weight of $19.5 \pm 4.3 \mathrm{~kg}$, with body condition score of $2.5 \pm 0.15$, were used. They were housed individually, with feeders and water available. After being weighed, identified, subjected to the control of endo- and ectoparasites and vaccinated against clostridial diseases, the animals underwent a 30-day period of adaptation to the management and facilities.

Feed was weighed and performed twice daily (8.00 and $15.00 \mathrm{~h}$ ) with complete feed and water always available. Daily, the leftovers were collected and weighed to match supply and to calculate dry matter intake. Animals were weighed every $14 \mathrm{~d}$ following $16 \mathrm{~h}$ of fasting, starting at day 0 .

For an estimation of total digestible nutrients (TDN), a digestibility trial was performed $40 \mathrm{~d}$ after the start of the experiment. To estimate fecal dry matter, a lignin enriched and purified $\left(\mathrm{LIPE}^{\circledR}\right)$ external marker was used by forced ingestion of one capsule of $250 \mathrm{mg} /$ day for $7 \mathrm{~d}$ : $2 \mathrm{~d}$ for adaptation and $5 \mathrm{~d}$ of feces collection. Feces were collected directly from the rectum once a day at 6:00, 8:00, 10:00, 12:00 and 14:00 h, as described by Ferreira et al. (2009). The estimated value of TDN was calculated with the aid of the equation described by Weiss (1999): TDN $=\mathrm{DCP}+(2.25 \times$ DEE) + DNFC + DNDF, where

$$
\text { Digestible crude protein }(\mathrm{DCP})=(\mathrm{CP} \text { intake }- \text { fecal }
$$
$\mathrm{CP})$,

$$
\text { Digestible ether extract }(\mathrm{DEE})=(\mathrm{EE} \text { ingested }-\mathrm{EE}
$$
feces),

Digestible non-fibrous carbohydrate $(\mathrm{DNFC})=$ (CNF ingested - CNF feces), and digestible neutral detergent fiber $(D N D F)=($ NDF ingested - fecal NDF $)$.

The experimental diets were isoproteic, with the base diet being formulated to meet the requirements for maintenance of animals of $24 \mathrm{~kg}$ and allowing weight gain of $200 \mathrm{~g}$ / day, according to the requirements prescribed by National Research Council-NRC (2007). Diets consisted of replacement levels of Tifton 85 hay with $\mathrm{CBH}$ at $0,33,66$, $100 \%$ (Table 1).

After $70 \mathrm{~d}$ on their respective experiment feeds (not including adaptation period), animals were subjected to a water diet and solid fasting for $16 \mathrm{~h}$. Immediately before slaughter they were weighed to obtain "weight at slaughter" (SW). At slaughter, the animals were stunned by concussion, followed by bleeding out through a section of the carotid artery and jugular vein. After skinning and evisceration, the head (sectioned at the atlanto-occipital joint) and the feet (sectioned at the metacarpal and metatarsal joints) were removed, and hot carcass weight (HCW) was registered. The gastrointestinal tract was weighed full and empty to determine the empty body weight (EBW) and biological yield $[\mathrm{BY}(\%)=\mathrm{HCW} / \mathrm{EBW} \times 100]$. 
Table 1 - Ingredients and chemical composition of the experimental diets.

\begin{tabular}{lcccc}
\hline \multirow{2}{*}{\multicolumn{1}{c}{ Ingredients $(\mathrm{g} / \mathrm{kg} \mathrm{DM})$}} & \multicolumn{4}{c}{ Level of replacement of Tifton 85 hay by castor bean hulls $(\%)$} \\
\cline { 2 - 5 } & 0 & 33 & 66 & 100 \\
\hline Spineless cactus & 400 & 400 & 400 & 400 \\
Tifton 85 hay & 300 & 200 & 100 & 0 \\
Castor bean hull & 0 & 99 & 198 & 297 \\
Soybean meal & 185 & 185 & 185 & 185 \\
Ground corn & 100 & 100 & 100 & 100 \\
Sodium chloride & 05 & 05 & 05 & 05 \\
Mineral mix & 10 & 10 & 10 & 10 \\
Urea & 0 & 01 & 02 & 03 \\
\hline & & Chemical composition & \\
\hline Dry matter $(\mathrm{g} / \mathrm{kg})$ & 249.9 & 250.1 & 250.2 & 250.4 \\
Crude protein $(\mathrm{g} / \mathrm{kg} \mathrm{DM})$ & 139.4 & 138.7 & 138.1 & 137.5 \\
Ether extract $(\mathrm{g} / \mathrm{kg} \mathrm{DM})$ & 16.0 & 15.1 & 14.1 & 13.1 \\
Mineral matter $(\mathrm{g} / \mathrm{kg} \mathrm{DM})$ & 106.8 & 104.3 & 101.9 & 99.4 \\
Neutral detergent fiber $(\mathrm{g} / \mathrm{kg} \mathrm{DM})$ & 404.9 & 402.3 & 399.6 & 397.0 \\
Acid detergent fiber $(\mathrm{g} / \mathrm{kg} \mathrm{DM})$ & 167.4 & 178.4 & 189.5 & 200.5 \\
Total digestible nutrients $(\mathrm{g} / \mathrm{kg} \mathrm{DM})$ & 626.1 & 624.9 & 566.0 & 561.1 \\
\hline
\end{tabular}

$\mathrm{DM}=$ Dry matter.

The carcasses were chilled for $24 \mathrm{~h}$ in a $4^{\circ} \mathrm{C}$ cold room and hung by means of hooks, with the metatarsal joints spaced at $17 \mathrm{~cm}$. After cooling, the carcasses were weighed, deducting the weight of the kidney and perirenal fat, to obtain the cold carcass weight (CCW) and to calculate the chilling losses $[\mathrm{CL}(\%)=\mathrm{HCW}-\mathrm{CCW} / \mathrm{HCW}$ $\times 100]$. The hot carcass yield was calculated as $[\mathrm{HCY}(\%)=$ $\mathrm{HCW} / \mathrm{SW} \times 100]$, and the commercial yield was calculated as $[\mathrm{CY}(\%)=\mathrm{CCW} / \mathrm{SW} \times 100]$. After the cooling period, the following measures were taken on the whole carcass as proposed by Cezar and Sousa (2007): internal length, thorax depth, thorax width, leg length, leg perimeter, rump width, rump perimeter, thoracic perimeter. Subsequently, the leg compactness index, ratio between rump width and leg length, and the carcass compactness index, the ratio between the cold carcass weight and the carcass inner length were calculated (CEZAR; SOUSA, 2007).

After the measurements, carcasses were cut in half and half of each carcass was weighed. The left half was sectioned into seven anatomic regions, using the methods adapted from Cezar and Sousa (2007), originating the commercial cuts: neck, shoulder, leg, loin, true ribs (section between the $1^{\text {st }}$ and $5^{\text {th }}$ thoracic vertebrae), false ribs (section between the $6^{\text {th }}$ and $13^{\text {th }}$ thoracic vertebrae) and sawcut. Our adaptation of the previous methodology consisted of dividing the ribs into true and false. We recorded the individual weights of each cut and then calculated the yield of each cut coming from the left half of the carcass compared to its reconstituted weight.

In the left half of the carcass, as proposed by Cezar and Sousa (2007), a cross-section between the $12^{\text {th }}$ and $13^{\text {th }}$ ribs was made to measure the longissimus muscle area (LMA) of the longissimus dorsi muscle by tracing the muscles contour on a transparent plastic sheet for later area determination using the average of three readings from a digital planimeter (Haff ${ }^{\oplus}$, Digiplan model). Additionally, a caliper was used to measure the thickness of the subcutaneous fat on the longissimus dorsi muscle section (between the last thoracic vertebra and the first lumbar) at two-thirds the total length of the LMA.

The experimental design was a randomized blocks, with animals assigned to these according to the animal's initial weight (Block $1=14.950 \pm 1.380 \mathrm{~kg}$; Block $2=17.210 \pm 1.450 \mathrm{~kg}$; Block $3=19.210 \pm 0.670 \mathrm{~kg}$; Block $4=20.800 \pm 0.355 \mathrm{~kg}$; Block $5=21.580 \pm 0.850 \mathrm{~kg}$ ). Data were tabulated and submitted for ANOVA and regression analysis with the aid of the statistical package SAEG (UNIVERSIDADE FEDERALDE VIÇOSA-UFV, 2007). Differences were considered significant at $P \leq 0.05$ unless otherwise noted. 


\section{RESULTS AND DISCUSSION}

Dry matter intake decreased linearly with the replacement of Tifton 85 hay with $\mathrm{CBH}$ (Table 2). The reductions in CPI and NDFI may be related to the decreased DMI because the diet had similar NDF and CP concentrations. The reduction in the TDNI can be attributed to the lower concentration of energy in the diets with the CBH inclusion and also the reduction in the DMI. The reduction in nutrient intake for animals consuming $\mathrm{CBH}$ may explain the decreases observed for body weight at slaughter, empty body weight, hot carcass weight and cold carcass weight, given the direct implication of these parameters on animal performance and that they are the natural markers of nutrient intake.

The carcass weights are consistent with the ranges proposed by Zapata et al. (2001) for the lamb carcasses, especially for crossbred animals. The authors stated that the average carcass weight should be approximately 15 $\mathrm{kg}$. The hot carcass yield, biological yield and commercial yield were not affected by replacement. The hot and commercial carcass yields are also in agreement with the yields presented by these authors and corroborate the findings by Vieira et al. (2010), who analyzed crossbred sheep fed a detoxified castor bean meal and obtained an average commercial yield of $42.84 \%$.

The chilling losses was not affected by replacement, but we observed high average values $(3,81 \%)$. The rate of chilling losses should be approximately $2.5 \%$; however, it may range from 1 to $7 \%$, based on the uniformity of the fat cover, sex, weight, temperature and humidity in the cold chamber (MARTINS et al., 2000). In this study, the high average values for the chilling losses is closely related to the small fat layer observed $(1.47 \mathrm{~mm})$, as the fat has a protective function of avoiding water loss by the carcass. Gerrard and Grant (2006) stated that the body's development of adipose tissue occurs after the peak of muscle growth. Pinheiro et al. (2007) observed higher subcutaneous fat in adult sheep compared with lambs. Santos et al. (2001) said that with advancing age and therefore increase the weight, the amount of fat in the

Table 2 - Dry matter intake, total digestible nutrients intake, crude protein intake, neutral detergent fiber intake and carcass characteristics of sheep fed castor bean hulls in replacement of Tifton 85 hay.

\begin{tabular}{|c|c|c|c|c|c|c|c|c|}
\hline \multirow[t]{2}{*}{ Item } & \multicolumn{4}{|c|}{$\begin{array}{l}\text { Level of replacement of Tifton } 85 \text { hay by castor } \\
\text { bean hulls }(\%)\end{array}$} & \multirow[t]{2}{*}{$\mathrm{CV}$} & \multicolumn{2}{|c|}{ Effect } & \multirow[t]{2}{*}{$\mathrm{R}^{2}$} \\
\hline & 0 & 33 & 66 & 100 & & $\mathrm{~L}$ & $\mathrm{Q}$ & \\
\hline DMI (kg/day) & 1.027 & 1.020 & 0.948 & 0.917 & 11.07 & $*^{1}$ & NS & 0.92 \\
\hline TDNI (kg/day) & 0.64 & 0.63 & 0.60 & 0.52 & 17.17 & $*^{2}$ & NS & 0.83 \\
\hline CPI (kg/day) & 0.145 & 0.144 & 0.133 & 0.127 & 11.05 & $*^{3}$ & NS & 0.93 \\
\hline NDFI (kg/day) & 0.381 & 0.380 & 0.340 & 0.332 & 11.20 & $*^{4}$ & NS & 0.84 \\
\hline SW (kg) & 32.84 & 31.59 & 30.37 & 28.67 & 5.32 & $* * *^{5}$ & NS & 0.99 \\
\hline EBW (kg) & 30.93 & 29.54 & 28.18 & 26.80 & 5.58 & $* * * 6$ & NS & 0.99 \\
\hline HCW (kg) & 15.13 & 14.29 & 13.58 & 12.78 & 6.69 & $* * *^{7}$ & NS & 0.99 \\
\hline CCW (kg) & 14.57 & 13.70 & 13.13 & 12.27 & 6.69 & $* * *^{8}$ & NS & 0.99 \\
\hline $\mathrm{HCY}(\%)$ & 46.01 & 45.05 & 44.72 & 44.63 & 3.09 & NS & NS & - \\
\hline BY (\%) & 48.86 & 48.21 & 48.20 & 47.75 & 2.84 & NS & NS & - \\
\hline CY (\%) & 44.29 & 43.21 & 43.21 & 42.85 & 3.24 & NS & NS & - \\
\hline CL (\%) & 3.74 & 4.09 & 3.39 & 4.01 & 15.29 & NS & NS & - \\
\hline Fat (mm) & 1.60 & 1.66 & 1.48 & 1.14 & 51.00 & NS & NS & - \\
\hline $\operatorname{LMA}\left(\mathrm{cm}^{2}\right)$ & 10.20 & 10.18 & 8.87 & 8.73 & 17.21 & $*^{9}$ & NS & 0.85 \\
\hline
\end{tabular}

DMI = dry matter intake; TDNI = total digestible nutrients intake; $\mathrm{CPI}=$ crude protein intake; NDFI = neutral detergent fiber intake; SW = body weight at slaughter; EBW = empty body weight; $\mathrm{HCW}=$ hot carcass weight; $\mathrm{CCW}=$ cold carcass weight; $\mathrm{HCY}$ $=$ hot carcass yield $; \mathrm{BY}=$ biological yield $; \mathrm{CY}=$ commercial yield; $\mathrm{CL}=$ chilling losses; $\mathrm{LMA}=$ longissimus muscle area; $\mathrm{L}=$ linear, $\mathrm{Q}=$ quadratic; $\mathrm{R}^{2}=$ determination coefficient; Significance: NS, Not Significant, ${ }^{*}, P \leq 0.05, * * P \leq 0.01, * * * P \leq 0.001 .^{1} \mathrm{v}=1.044-$ $0.0012 \mathrm{CH} ;{ }^{2} \hat{\mathrm{Y}}=0.663-0.0012 \mathrm{CH} ;{ }^{3} \hat{\mathrm{Y}}=0.147-0.0002 \mathrm{CH} ;{ }^{4} \hat{\mathrm{Y}}=0.389-0.0006 \mathrm{CH} ;{ }^{5} \hat{\mathrm{Y}}=33.358-0.0412 \mathrm{XCH} ;{ }^{6} \hat{\mathrm{Y}}=31.361-$ $0.0413 \mathrm{CH} ;{ }^{7} \hat{\mathrm{Y}}=15.367-0.0232 \mathrm{CH} ;{ }^{8} \hat{\mathrm{Y}}=14.792-0.0224 \mathrm{CH} ;{ }^{9} \hat{\mathrm{Y}}=10.455-0.0171 \mathrm{CH} . \mathrm{CH}=\%$ Castor bean hulls in replacement of Tifton 85 hay.

Ciênc. agrotec., Lavras, v. 36, n. 1, p. 85-93, jan./fev., 2013 
carcass increases. Hood and Thornton (1979) found that there is an increase in the number of fat cells in sheep Santa Ines in the growth phase between 28 and $45 \mathrm{~kg}$ body weight. In this study, the confinement time was pre-set at $70 \mathrm{~d}$; therefore, the low amount of subcutaneous fat could be a consequence of the slaughter occurring before muscle growth has reached its plateau, namely before the adipose tissue started its development. This hypothesis is gaining more credence with the observation that there was no variation in the thickness of subcutaneous fat among treatments. Thus, the thinness of the fat may not have been due to the low energy intake but due to the chronology of body development.

Additionally, Pires et al. (2006) found that when sheep were slaughtered at an average live weight of $30 \mathrm{~kg}$ after being fed on diets with increasing levels of ADF, the average fat cover thickness value was only $0.06 \mathrm{~mm}$ greater than that observed in this work. These authors also found a high average value of chilling losses of $3.12 \%$. According Cardoso et al. (2006), diets with a high fiber concentration necessarily have low energy density and ruminal fill limit the intake, reducing animal performance.

Our results of fat cover thickness indicate that more research is needed with lambs without defined breed at different slaughter weights to determine the evolution of the fat cover In our experiment the animals had different energy intake, different slaughter weights and did not differ in fat cover thickness.

The LMA decreased linearly with the replacement of Tifton 85 hay with CBH. The LMA is among the largest muscles of the carcass from livestock species and its cross- sectional area is often used as a predictor of muscularity (GERRAR; GRANT, 2006; YÁÑEZ et al., 2006). Therefore, its linear decline is consistent with decreased body weight. The LMA, according to Zapata et al. (2001), correlates positively with the animal's age. This finding justifies the median values found in this work $\left(10.2 \mathrm{~cm}^{2}\right.$ to $\left.8.7 \mathrm{~cm}^{2}\right)$ because the average age of the animals used in this experiment was approximately $7 \pm 1.4$ months.

Weights of all meat cuts decreased linearly with the replacement of Tifton 85 hay with $\mathrm{CBH}$ (Table 3), which was also accompanied by decreased energy intake according to the replacement percentages. Energy is the most limiting nutritional component in sheep production and the deficit in energy intake results in reduced animal performance, with reflections on the productive indices, such as carcass yield and its cuts (PIOLA JUNIOR et al. 2009; EZEQUIEL et al., 2006). Alves et al. (2003) and Gonzaga Neto et al. (2006) also reported the importance of energy intake in sheep meat production.

With the exception of the neck, for which a quadratic effect was observed with a minimum yield of $9.84 \%$ at $56.9 \%$ replacement, there was no effect of $\mathrm{CBH}$ substitution on the cut yields (Table 4). These data agree with the law of anatomical harmony that states that in carcasses of similar weight and fat quantities, almost all body parts are present in similar proportions, as long as genotype is uniform (BOCCARD; DUMONT, 1960).

Despite the decrease observed for the weights of cuts, the results obtained from our work, especially the yield data, can be considered satisfactory. The most prized lamb carcass cuts come from the leg, shoulder and loin;

Table 3 - Weight of commercial cuts of sheep fed castor bean hulls in replacement of Tifton 85 hay.

\begin{tabular}{|c|c|c|c|c|c|c|c|c|}
\hline \multirow[t]{2}{*}{ Item $(\mathrm{kg})$} & \multicolumn{4}{|c|}{$\begin{array}{l}\text { Level of replacement of Tifton } 85 \text { hay by castor } \\
\text { bean hulls }(\%)\end{array}$} & \multirow[t]{2}{*}{$\mathrm{CV}$} & \multicolumn{2}{|c|}{ Effect } & \multirow[t]{2}{*}{$\mathrm{R}^{2}$} \\
\hline & 0 & 33 & 66 & 100 & & $\mathrm{~L}$ & Q & \\
\hline Neck & 0.81 & 0.73 & 0.62 & 0.68 & 13.79 & $* *^{1}$ & NS & 0.63 \\
\hline Shoulder & 1.46 & 1.30 & 1.26 & 1.17 & 8.97 & $* * *^{2}$ & NS & 0.94 \\
\hline $\mathrm{TR}$ & 0.49 & 0.49 & 0.45 & 0.39 & 19.23 & $*^{3}$ & NS & 0.88 \\
\hline FR & 0.75 & 0.71 & 0.65 & 0.62 & 9.96 & $* * * 4$ & NS & 0.99 \\
\hline Sawcut & 0.80 & 0.80 & 0.74 & 0.68 & 13.38 & $*^{5}$ & NS & 0.86 \\
\hline Loin & 0.60 & 0.56 & 0.56 & 0.48 & 9.07 & $* * * 6$ & NS & 0.87 \\
\hline Leg & 2.38 & 2.31 & 2.19 & 2.07 & 7.54 & $* *^{7}$ & NS & 0.99 \\
\hline
\end{tabular}

TR = true ribs, FR = false ribs; $\mathrm{L}=$ linear, $\mathrm{Q}=$ quadratic; $\mathrm{R}^{2}=$ determination coefficient; Significance: NS, Not Significant, $*, P$ $<0.05$, ** $P<0.01$, *** $P<0001 .{ }^{1} \hat{\mathrm{Y}}=0.8142-0.0015 \mathrm{CH} ;{ }^{2} \hat{\mathrm{Y}}=1.4458-0.0027 \mathrm{CH} ;{ }^{3} \hat{\mathrm{Y}}=0.5184-0.0013 \mathrm{CH} ;{ }^{4} \hat{\mathrm{Y}}=0.7701-$ $0.0013 \mathrm{CH} ;{ }^{5} \hat{\mathrm{Y}}=0.8266-0.0012 \mathrm{CH} ;{ }^{6} \hat{\mathrm{Y}}=0.6122-0.0011 \mathrm{CH} ;{ }^{7} \hat{\mathrm{Y}}=2.433-0.0032 \mathrm{CH} . \mathrm{CH}=\%$ Castor bean hulls in replacement of Tifton 85 hay 
thus, the greater their percentage of the carcass, the greater its value will be. Zundt et al. (2003) indicated that the proper conformation includes the proportional development of the different anatomical regions belonging to it. Thus the best conformations are achieved when the parts of greatest commercial value are well pronounced. In our study, the percentage of premium cuts of carcass remained at approximately $60 \%$, which could add more value to the final product. Moreover, the low yield of little valued cuts such as the neck and sawcut, keep the meat within the requirements of the consumer market.

The rump, thoracic and leg perimeters decreased linearly with the replacement of Tifton 85 hay by $\mathrm{CBH}$; however, no other measurements were influenced (Table 5).

Lamb body development occurs in the following sequence: bone, muscle and fat (GERRARD; GRANT, 2006). Thus, after birth, it is expected that the animal develops early bone structure and sequentially has an increase in muscle mass. Finally, the animal should have a surface finish related to the fat deposited. The morphological results of this study showed that the linear measurements did not vary with energy intake; however, perimeter measurements, which are dependent on muscle development, linearly decreased, showing the direct influence of energy intake. Araújo Filho et al. (2007)

Table 4 - Yield of commercial cuts of sheep fed on castor bean hulls in replacement of Tifton 85 hay.

\begin{tabular}{|c|c|c|c|c|c|c|c|c|}
\hline \multirow[t]{2}{*}{ Item $(\%)$} & \multicolumn{4}{|c|}{$\begin{array}{l}\text { Level of replacement of Tifton } 85 \text { hay by castor } \\
\text { bean hulls }(\%)\end{array}$} & \multirow[t]{2}{*}{$\mathrm{CV}$} & \multicolumn{2}{|c|}{ Effect } & \multirow[t]{2}{*}{$\mathrm{R}^{2}$} \\
\hline & 0 & 33 & 66 & 100 & & $\mathrm{~L}$ & Q & \\
\hline Neck & 11.08 & 10.61 & 9.26 & 11.17 & 12.74 & NS & $*^{1}$ & 0.63 \\
\hline Shoulder & 20.03 & 18.96 & 19.09 & 19.26 & 5.49 & NS & NS & - \\
\hline $\mathrm{TR}$ & 6.76 & 7.05 & 6.71 & 6.51 & 15.80 & NS & NS & - \\
\hline FR & 10.23 & 10.21 & 9.77 & 10.19 & 7.64 & NS & NS & - \\
\hline Sawcut & 10.96 & 11.66 & 11.03 & 11.20 & 10.12 & NS & NS & - \\
\hline Loin & 8.24 & 8.12 & 8.31 & 7.79 & 8.12 & NS & NS & - \\
\hline Leg & 32.86 & 33.54 & 32.95 & 34.02 & 5.19 & NS & NS & - \\
\hline
\end{tabular}

$\mathrm{TR}=$ true ribs, $\mathrm{FR}=$ false ribs $; \mathrm{L}=$ linear, $\mathrm{Q}=$ quadratic $\mathrm{R}^{2}=$ determination coefficient; Significance: NS, Not Significant, *, $\mathrm{P}<0.05$, $* * \mathrm{P}<0.01, * * * \mathrm{P}<0001 .{ }^{1} \hat{\mathrm{Y}}=11.456-0.0569 \mathrm{CH}+0,0005 \mathrm{CH}^{2} . \mathrm{CH}=\%$ Castor bean hulls in replacement of Tifton 85 hay.

Table 5 - Carcass measurements of sheep fed castor bean hulls in replacement of Tifton 85 hay.

\begin{tabular}{|c|c|c|c|c|c|c|c|c|}
\hline \multirow[t]{2}{*}{ Item } & \multicolumn{4}{|c|}{$\begin{array}{l}\text { Level of replacement of Tifton } 85 \text { hay by } \\
\text { castor bean hulls }(\%)\end{array}$} & \multirow[t]{2}{*}{$\mathrm{CV}$} & \multicolumn{2}{|c|}{ Effect } & \multirow[t]{2}{*}{$\mathrm{R}^{2}$} \\
\hline & 0 & 33 & 66 & 100 & & $\mathrm{~L}$ & Q & \\
\hline Rump width (cm) & 15.22 & 15.00 & 14.73 & 14.51 & 6.15 & NS & NS & - \\
\hline Thorax width (cm) & 21.62 & 21.53 & 20.98 & 20.75 & 6.36 & NS & NS & - \\
\hline Rump perimeter $(\mathrm{cm})$ & 58.97 & 57.88 & 57.35 & 56.00 & 3.34 & $* * 1$ & NS & 0.98 \\
\hline Internal length (cm) & 61.36 & 61.27 & 60.97 & 59.23 & 4.06 & NS & NS & - \\
\hline Leg length $(\mathrm{cm})$ & 41.77 & 41.42 & 42.24 & 40.77 & 3.03 & NS & NS & - \\
\hline Thorax depth $(\mathrm{cm})$ & 26.52 & 26.50 & 26.51 & 25.80 & 3.34 & NS & NS & - \\
\hline Thoracic perimeter $(\mathrm{cm})$ & 68.02 & 67.84 & 67.32 & 65.43 & 2.79 & $*^{2}$ & NS & 0.81 \\
\hline Leg perimeter $(\mathrm{cm})$ & 32.78 & 31.74 & 31.55 & 30.98 & 4.35 & $*^{3}$ & NS & 0.92 \\
\hline LCI & 0.36 & 0.36 & 0.35 & 0.36 & 6.27 & NS & NS & - \\
\hline $\mathrm{CCI}(\mathrm{kg} / \mathrm{cm})$ & 0.24 & 0.22 & 0.22 & 0.21 & 6.16 & $* * * 4$ & NS & 0.97 \\
\hline
\end{tabular}

LCI = leg compactness index, $\mathrm{CCI}=$ carcass compactness index, $\mathrm{L}=$ linear, $\mathrm{Q}=$ quadratic; $\mathrm{R}^{2}=$ determination coefficient; Significance: NS, Not Significant, $*, P<0.05, * * P<0.01$, *** $P<0001 .{ }^{1} \hat{\mathrm{Y}}=59.437-0.0284 \mathrm{CH} ;{ }^{2} \hat{\mathrm{Y}}=68.921-0.0249 \mathrm{CH} ;{ }^{3} \hat{\mathrm{Y}}=$ $32.773-0.0168 \mathrm{CH} ;{ }^{4} \hat{\mathrm{Y}}=0.2385-0.0003 \mathrm{CH} . \mathrm{CH}=\%$ Castor bean hulls in replacement of Tifton 85 hay. 
reported that diets with greater energy levels tend to foster greater tissue deposition, increasing morphometric measures of carcass. These authors observed greater thoracic perimeter $(67.33 \mathrm{~cm})$ for animals fed diets containing 2.94 MCal ME/kg DM when compared to animals fed diets containing 2.50 Mcal ME/kg DM $(65.42 \mathrm{~cm})$.

The lack of an effect of Tifton 85 hay replacement with $\mathrm{CBH}$ on the longitudinal measurements could be explained by the fact that the animals were only subjected to the experimental diet when they were approximately $7 \pm 1.4$ months age. As bone development is early compared to other tissues, there was no influence of diet on measurements that depend directly on bone development.

The LCI was not influenced by the dietary substitution, but there was a linear decrease for the CCI (Table 5). Carcass compactness index depends on the cold carcass weight, which also decreased linearly with the substitution. The CCI values obtained $(0.24-0.21)$ are very close to those obtained by Medeiros et al. (2009) when they subjected Morada Nova sheep to different levels of concentrate and thus different energy levels. These authors obtained the same effect by this substitution, i.e., greater levels of carcass compactness (0.24) for animals provided greater energy intake, and lower CCI (0.22) for animals fed diets with lower energy density.

\section{CONCLUSIONS}

The replacement of Tifton 85 hay with $\mathrm{CBH}$ in sheep diets negatively influences body weight at slaughter, hot and cold carcass weight, the weights of all commercial cuts and morphometric measurements. Despite the observed results, factors such as the availability and prices of hay and $\mathrm{CBH}$ can justify the choice of alternative ingredients because the likely reduction in costs may offset losses related to the carcass weight and commercial cuts.

\section{REFERENCES}

ALVES, K.S. et al. Níveis de energia em dietas para ovinos Santa Inês: Características de carcaça e constituintes corporais. Revista Brasileira de Zootecnia, Viçosa, v.32, n.6, p.1927-1936, 2003 (supl. 2).

ARAÚJO FILHO, J.T. et al. Efeito de dieta e genótipo sobre medidas morfométricas e não constituintes da carcaça de cordeiros deslanados terminados em confinamento. Revista Brasileira de Saúde e Produção Animal, Salvador, v.8, n.4, p.394-404, 2007.
ATAÍDE JÚNIOR, J.R. et al. Valor nutritivo do feno de capim-tifton 85 (Cynodon spp.) em diferentes idades de rebrota, em ovinos. Revista Brasileira de Zootecnia, Viçosa, v.29, n.6, p.2193-2199, 2000 (supl. 2).

BOCCARD , R.; DUMONT, B.L. Etude de o production de o viande chez on ovins. II variation de l'importance relative on differents régions corporelles de l'agneau de boucherie. Annales de Zootechnie, Versailles, v.9, n.4, p.355-365, 1960.

BRUNSCHIWIG, C.; MOUSSAVOU, W.; BLIN, J. Use of bioethanol for biodiesel production. Progress in Energy and Combustion Science, Amsterdam, v.38, n.2, p.283301, 2012.

CARDOSO, A.R. et al. Consumo de nutrientes e desempenho de cordeiros alimentados com dietas que contêm diferentes níveis de fibra em detergente neutro. Ciência Rural, Santa Maria, v.36, n.1, p.215-221, 2006.

CESAR, A. S.; BATALHA, M. O. Biodiesel production from castor oil in Brazil: A difficult reality. Energy Policy, Amsterdam, v.38, n.8, p.4031-4039, 2010.

CEZAR, M.F.; SOUSA, W.H. Carcaças ovinas e caprinas: obtenção, avaliação e tipificação. Campina Grande: Editora Universidade Federal de Campina Grande, 2007. 120p.

EZEQUIEL, J. M. B. et al. Desempenho e características de carcaça de bovinos Nelore alimentados com bagaço de cana-de-açúcar e diferentes fontes de energéticas.

Revista Brasileira de Zootecnia, Viçosa, v.35, n.5, p.2050-2057, 2006.

FERREIRA, M.A. et al. Avaliação de indicadores em estudos com ruminantes: digestibilidade. Revista Brasileira de Zootecnia, Viçosa, v.38, n.8, p.1568-1573, 2009.

GERRARD, D.E.; GRANT, A.L. Principles of animal growth and development. Revised Printing. Purdue University, E.U.A.:Kendall/Hunt Publishing Company, 2006. 264p.

GOMES, F.H.T. et al. Composição bromatológica e degradação in situ de subprodutos da cadeia do biodiesel. Revista Científica de Produção Animal, Teresina, v.11, n.2, p.144-156, 2009. 
GONZAGA NETO, S. et al. Características quantitativas da carcaça de cordeiros deslanados Morada Nova em função da relação volumoso: concentrado na dieta. Revista Brasileira de Zootecnia, Viçosa, v.35, n.4, p.1487-1495, 2006.

HOOD, R.L.; THORNTON, R.F. The cellularity of ovine adipose tissue. Australian Journal of Agricultural Research, Melbourne, v.30, n.1, p.153-161, 1979.

JORGE, A.M. et al. Desempenho produtivo de animais de quatro raças zebuínas abatidos em três estádios de maturidade. 2. Características da carcaça. Revista Brasileira de Zootecnia, Viçosa, v.28, n.2, p.381-387, 1999.

MARTINS, R.C. et al. Peso vivo ao abate como indicador do peso e das características quantitativas e qualitativas das carcaças em ovinos jovens da raça Ideal. Bagé: Embrapa Pecuária Sul, 2000. 29p. (Boletim de Pesquisa e Desenvolvimento, 21).

MEDEIROS, G.R. et al. Efeito dos níveis de concentrado sobre as características de carcaça de ovinos Morada Nova em confinamento. Revista Brasileira de

Zootecnia, Viçosa, v.38, n.4, p.718-727, 2009.

MENDIETA-ARAICO, B. et al. Moringa (Moringa oleifera) leaf meal as a source of protein in locally produced concentrates for dairy cows fed low protein diets in tropical areas. Livestock Science, Amsterdam, v.137, n.3, p.10-17, 2011.

MOLINAALCAIDE, E.; YÁÑES RUIZ, D.R. Potential use of olive by-products in ruminant feeding: A review. Livestock Science, Amsterdam, v.147, n.3, p.247-264, 2008.

NATIONAL RESEARCH COUNCIL-NRC. Nutrient Requirements of Small Ruminants: Sheep, Goats, Cervids, and New World Camelids. 1.ed.

Washington, D.C.: National Academy Press, 2007. $384 \mathrm{p}$.

OLIVEIRA, M.V.M. et al. Rendimento de carcaça, mensurações e peso de cortes comerciais de cordeiros Santa Inês e Bergamácia alimentados com dejetos de suínos em confinamento. Revista Brasileira de Zootecnia, Viçosa, v.31, n.3, p.1451-1458, 2002 (suplemento).
PINHEIRO, R.S.B. et al. Composição tecidual dos cortes da carcaça de ovinos jovens e adultos. Pesquisa Agropecuária Brasileira, Brasília, v.42, n.4, p.565-571, 2007.

PIOLA JUNIOR, W. et al. Níveis de energia na alimentação de cordeiros em confinamento e composição regional e tecidual das carcaças. Revista Brasileira de Zootecnia, Viçosa, v.38, n.9, p.1797-1802, 2009.

PIRES, C.C. et al. Características da carcaça de cordeiros alimentados com dietas contendo diferentes níveis de fibra em detergente neutro. Revista Brasileira de Zootecnia, Viçosa, v.35, n.5, p.20582065, 2006.

REIS, W. U. et al. Características da carcaça de cordeiros alimentados com dietas contendo grãos de milho conservados em diferentes formas. Revista Brasileira de Zootecnia, Viçosa, v.30, n.4, p.1308-1315, 2001.

SANTOS, S. F. et al. Efeito da casca de mamona sobre a produção, composição e ácidos graxos do leite de cabra. Archivos de Zootecnia, Córdoba, v.60, n.229, p.113-122, 2011.

SANTOS, C.L. et al. Desenvolvimento relativo dos tecido ósseo, muscular e adiposo dos cortes da carcaça de cordeiros Santa Inês. Revista Brasileira de Zootecnia, Viçosa, v.30, n.2, p.487-492, 2001.

UNIVERSIDADE FEDERALDE VIÇOSA - UFV. Sistema de análises estatísticas e genéticas -SAEG. Viçosa, MG: UFV, 2007.301p.

VIEIRA, M. M. M. et al. Características da carcaça e dos componentes não-carcaça em ovinos alimentados com rações à base de farelo de mamona. Revista Brasileira de Saúde e Produção Animal, Salvador, v.11, n.1, p.140$149,2010$.

WEISS, W. Energy prediction equations for ruminant feeds. In: CORNELL NUTRITIONCONFERENCE FOR FEED MANUFACTURERS, 61., 1999, Ithaca.

Proceedings... Ithaca: Cornell University, 1999. p.176-185.

YÁÑEZ, E.A. et al. Restrição alimentar em caprinos: rendimento, cortes comerciais e composição da carcaçaRevista Brasileira de Zootecnia, Viçosa, v.35, n.5, p. 2093-2100, 2006. 
ZAPATA, J. F. F. et al. Características de carcaça de pequenos ruminantes do Nordeste do Brasil. Ciência Animal, Fortaleza, v.11, n.2, p. 79-86, 2001.

ZUNDT, M. et al. Desempenho e características de carcaça de cordeiros Santa Inês confinados, filhos de ovelhas submetidas à suplementação alimentar durante a gestação. Revista Brasileira de Zootecnia, Viçosa, v.35, n.3, p.928-935, 2006.

ZUNDT, M. et al. Características de carcaça de cordeiros terminados em confinamento, com dietas contendo diferentes níveis protéicos. Ciência Rural, Santa Maria, v.33, n.3, p.565-571, 2003. 
